ignorance of veterinary science, even in the highset quarters, and by conservatism and lack of co-operation among the farming community.

Mr. C. F. Carr, editor of the Southern Daily Echo, gave a short talk on "Science and the Press", in which he expressed the view that unless the newspaper industry is prepared to encourage research directed towards speeding up and improving its own productive processes, it will soon be completely out-done by broadcasting. He hoped they would get down to this and also that the Press might be to a much greater extent the vehicle for disseminating scientific knowledge to the public.

Dr. Harry Barron, head of the Plastics Department of Pirelli-General Cable Works Ltd., spoke on the subject of synthetic rubber. He explained how vital rubber is, not only to the war machine, but also to industry as a whole; no longer can oil and steel be regarded as the only criteria of a nation's ability to make war. Since the loss of natural rubber supplies in the Far East, Great Britain may have difficulty in lasting out this year on existing stocks. The U.S.S.R. and Germany both built synthetic rubber industries years ago ; the United States started some time ago to build up such an industry; but in Great Britain, owing to the continual obstruction of powerful vested interests, no start has been made even now. Not even the essential raw material - carbide - is available, as we have no carbide industry. The American industry will not be in a position for a year or two to supply us with quantities large enough; 50,000 tons a year has been glibly talked about, but the total production this year is unlikely to exceed 40,000 tons. We need to be most economical in the use of rubber, and to save every scrap for reclamation. Dr. Barron thought we should set about solving the problem immediately by building quite small pilot plants, in order to gain experience in the processes and to train the technicians needed.

The evening session was presided over by Dr. Barron, who read out a letter from the Association of Scientific Workers to branches in the radio and electrical industries, asking for information about the misuse, wastage or under-employment of technical resources, about which a Committee of the War Cabinet has asked for investigations to be made.

The first speaker was Mr. C. E. G. Bailey, of the Mullard Radio Valve Co. He spoke on "Radio Research and the War", and began by describing the peace-time condition of the industry, in which, except for television development carried on almost exclusively by the large firms, technicians were mostly engaged in thinking out sales points, such as fancy tuning scales and push-button circuits. Little real research was done. At the same time, the few Government establishments maintained were hampered by inter-Services rivalry and by the difficulty of obtaining the best scientific brains, owing to humdrum conditions of work. The crisis of war has made plain the need-previously seen only vaguelyfor the industry to change from the spirit of commercial competition to one of technical co-operation if real progress is to be made. Even at this eleventh hour, co-operation between the Services, between firms and between Services and firms, and the proper allocation of jobs, are only just being organized on a reasonable scale.

Turning to the subject of post-war reconstruction, Mr. Bailey said that this is a two-edged term. It is usually interpreted by employers as meaning that they must carve a niche for themselves in the post- war markets, so as to "avoid dismissing their employees". However, we must not employ technicians now in designing broadcast receivers on the old competitive lines, when their services are so vitally needed for war work.

In the subsequent discussion, one speaker suggested that the Association of Scientific Workers should be ready to put forward a general plan for the post-war industry, which would indicate future lines of research and ensure that ample work is available.

The final contribution was by Mr. Alexandra Orba, of University College, Southampton, on "Technical Education". $\mathrm{He}$ outlined a plan for education designed to produce the technicians required for immediate war-time needs as rapidly and efficiently as possible, and at the same time to lay the foundation for a more satisfactory educational system after the War. We shall then have a larger number of people with technical knowledge than ever before, and we must take full advantage of this to build up a different attitude towards seience and its cultural value. We must see that the vocational training given is related to the needs of society at the time and the estimated future needs; we must train staffs for all grades of work in industry, for executive and administrative posts as well as technical ones.

There was considerable discussion following this address, and a resolution. "That the Board of Education be urged to give consideration to the need for teaching all school children something of the organization and processes of modern industry" was carried.

The Conference served a useful purpose in focusing attention in the area on the need for the application of scientific effort both immediately and for the future, and a number of resolutions arising out of the papers which had been discussed were passed.

\section{LONDON SCIENTIFIC FILM SOCIETY}

THE London Scientific Film Society gave a 1 demonstration of films on May 16 at the Imperial Institute cinema. Dr. Julian Huxley introduced the film "Galapagos" and led a discussion on it afterwards. The film was made by the Dartington Hall Film Unit under the direction of $\mathrm{Mr}$. William Hunter and Mr. David Lack and was photographed by Mr. Richard Leacock. It illustrates the comparatively free adaptive evolution of new types, in absence of competition, from original single colonizations on a group of oceanic islands. The extent of the differences from the mainland forms depends on the time that elapses since the colonization. In such cases, where the pressure of natural selection is light, the animals are not as well equipped to fill their environmental niches as are mainland forms. For example, there is a member of the gull tribe, the close ancestors of which are water birds, which nests in the trees although it still retains webbed feet; and the finches have evolved a range of species to exploit the available food supplies, although the shape of their beak, unlike those of most mainland birds, does not always give a precise indication of the food habits of the bird.

Dr. Huxley also pointed out that there is a tendency to gigantism in absence of competitors, as shown on the Galapagos by the giant tortoises and iguanas, and that animals can extend to unusual habitats, as 
shown here by the unique sea lizard and the red land crabs.

The film is well photographed, but it is to be regretted that there are no pictures of the mainland birds from which the island forms evolved and that the captions are scarcely sufficient to explain the purpose of the film. It was pointed out that the absence of sufficient funds explained some of the unavoidable deficiencies of the film and why it was only available on $16 \mathrm{~mm}$. silent film.

In the discussion which followed it was asked whether any steps are being taken to preserve such valuable films, which show animals that are fast becoming extinct. It was explained that the National Film Library of the British Film Institute has as one of its aims the preservation of films which illustrate the development of the cinema and of social history, but that it does not collect films specially for their scientific or technical content. The Scientific Films Committee of the Association of Scientific Workers (on whose recommendations the programmes of the London Scientific Film Society are largely made) has recently made a plea to the National Film Library for the preservation of scientific films and has made out a list of those that it considers should be obtained now. "Galapagos" is one of them.

Other films shown by the Society at this meeting were: "Propeller Making", "This is Colour" (an Imperial Chemical Industries film in Technicolor about dyes), "A Few Ounces a Day" and an excellent film epic recently arrived from the United States of the building of the Boulder Dam in Colorado.

\section{FORTHCOMING EVENTS}

\section{Saturday, May 30}

NUTRITION SocreTr (at the London School of Hygiene and Tropical Medicine, Keppel Street, London, W.C.1), at 11 a.m.-Conference on "Problems of Collective Feeding in War-time".

Monday, June I

Royal Grographrcal Society (at Kensington Gore, London, S.W.7), at 5 p.m.-Geographical Films.

\section{Friday, June 5}

Geologists' Association (in the Rooms of the Geological Society of London, Burlington House, Piceadilly, London, W.1), at 5.30 p.m. -Prof. Frank Debenham: "Shelly Drift in the Antarctic".

\section{APPOINTMENTS VACANT}

APPLICATIONS are invited for the following appointments on or before the dates mentioned:

HEAD OF DEPARTMENT OF THE JUNIOR TECHNICAI SCHOOL FOR Burning in the Bournemouth Municipal College-The Director of BuILDING in the Bournemouth Municipal Colle
Education, Town Hall, Bournemouth (June 4).

Lectureship in Chinical Pathology-The Secretary, University College, Cork (June 6).

UNIVERSITY ChaIR OF BIochamistry tenable at St. Thomas's Hospital Medical School-The Academic Registrar, University of London, Richmond College, Richmond, Surrey (June 8).

Lecturer in Pharmacedtical Subjects-The Principal, Leicester College of Technology and Commerce, The Newarke, Leicest 1 (June 13).

Assistant Mistress to teaOH BIology and Subsidiary Chemistry -The Clerk to the Governors, South-East Essex Technical College, Longbridge Road, Dagenham (June 13).

Chemrst to assist in an investigation on the production of organic fertilisers-Prof. H. A. D. Neville, The University, Reading.

MaChanioal ENGINeER For Mine oN THE GOLD COAST engaged on production of essential war material-The Secretary, Ministry of Labour and National Service, Central Register (Ref.' O.M.C. 968), Public Trustee Office, Sardinia Street, Kingsway, London, W.c.2.

\section{REPORTS and other PUBLICATIONS}

\author{
(not included in the monthly Books Supplement)
}

\section{Great Britain and Iraland} Royal Society for the Protection of Birds. Fifty-first Annual Report,
January 1st to December 31st, 1941 ; with Proceedings of Annual Meeting, 1942. Pp. 40. (London: Royal Society for the Protection of Birds.) 1942. Pp. 40. (London: Royal Society for the Protection Annual Report of the Oundle School Natural History Society. Pp. 24. (Oundle: Oundle Sehool.) Reports on Progress in Physics. Vol. 8 (1941). General Editor
W. B. Mann. Pp. iv +372. (London: Physical Society.) 258. net. [55 Sheffield City Libraries. Research Bulletin No. 6: Machining of Metals. Pp. 46. (Sheffield: Central Library.) Geological Survey of Great Britain: Scotland. Wartime Pamphlet No. 24: The Limestone Coal Group of the Glasgow District. By Dr. M. Macgregor : with Note on Palæontology of Principal Musselbands, by Dr. J. Weir and Dr. D. Leitch. Pp. 22. (London: Geo-
logical Survey and Museum.) 1s. 1d.

Proceedings of the Royal Society of Edinburgh, Section B (Biology) Vol, 61, Part 2, No. 17: A Study of the Cytoplasmic Inclusions durin the Spermatogenesis of the Mouse. By Dr. R. A. R. Gresson. $\mathrm{Pn}$. 197-210 (2 plates). 1s. 3d. Vol. 61, Part 2, No. 18: Variation in Gryphaea incurva (Sow.) from the Lower Lias of Loch Aline, Argyll. By Rhona M. Maclennan and Dr. A. E. Trueman. Pp. 211-232, 18. 9d. (Edinburgh and London: Oliver and Boyd.) [115 Geological Survey of Great Britain : Scotland. Wartime Pamphlet No. 13 : Limestones of Scotland, Area 3: East-Central Scotland. By D. Haldane and Dr. J. B. Simpson; with Analyses by Dr. A. Muir and H. G. M. Hardie. Pp. 30. (London: Geological Survey

Annual Report for 1941 of the Research Departments of the College of the Pharmaceutical Society. Pp. 36. (London: Pharmaceutical Society.)

Burton-on-Trent Natural History and Archæological Society. Local Records for 1941. Pp. 25. (Burton-on-Trent: Natural History and Archæological Society.) 18

\section{Other Countries} University of Illinois: Engineering Experiment Station. Circular
Series No. 42: Papers presented at the Twenty-eighth Annual Conference on Highway Engineering held at the University of Illinois, ference on Highway Engineering held at the University of nllinois, March 5-7, 1941. Pp. 91. 50 cents. Bulletin Series No. 333: The Suitability of Stabilized Soil for Building Construction. By Edwin L.
Hansen. Pp. 40. 45 cents. Bulletin Series No. 329: A Study of the Hansen. Pp. 40. 45 cents. Bulletin Series No. 329: A Study of the Collapsing Pressure of Thin-Walled Cylinders. By Rolland George

Bernice P. Bishop Museum. Bulletin 170: Land Utilization in American Samoa. By John Wesley Coulter. Pp. $48+2$ plates. Bul letin 171: Report of the Director for 1940. By Peter H. Buck (Te Rangi Hiroa). Pp. 33. (Honolulu: Bernice P. Bishop Museum.) [115

U.S. Department of Agriculture. Farmers' Bulletin No. 1885 : Treatment of White Pines infected with Blister Rust. By J. F. Martin and G. F. Gravatt. Pp. $\mathrm{ii}+28$. 10 cents. Miscellaneous Publication No. 468: Raspberry Fruitworms and related Species. By H. S. Barber. Pp. 32 . 10 cents. Technical Bulletin No. 801 : Insecticidal Lynn H. Dawsey. Pp. 16. 5 cents. (Washington, D.C. : Government Lynn H. Dawsey.

\1.15

Occasional Papers of the Bernice P. Bishop Museum. Vol. 16, No. 9: Encyrtidæ of the Marquesas and Society Islands (Hymenoptera. Chalcidoidea). By P. H. Timberlake. Pp. 215-230. Vol. 16, No. 10: Psammocharidæ from the Solomon Islands, Prince of Wales Island, and New Caledonia. By Nathan Banks. Vol. 16, No. 11: The Hippoboscidæ of Oceania (Diptera). By Joseph C. Bequaert. Pp. 247292. Vol. 16, No. 12: Viability of Coconut Seeds after Floating in the Sea. By Charles Howard Edmondson. Pp. 293-304. Vol. 16, No. 13: The Isopod Crustacea of the Hawaiian Islands, 2: Aseilota. By Milton A. Miller. Pp. 305-320. Vol. 16, No. 15: Miscellaneous Notes on Hawaiian Plants, 2. By F. Raymond Fosberg. Pp. 337348. Vol, 16, No. 16: The Genus Araucaricola in Fiji (Coleoptera, Tenebrionidæ). By Elwood C. Zimmerman. Pp. 349-356. (Honolulu Bernice P. Bishop Museum.)

[115

Field Museum of Natural History. Anthropological Series, Vol. 33, No. 2: Kinship System of the Seminole. By Alexander Spoehr. History.) 50 cents.

$[135$

Commonwealth of Australia : Council for Scientific and Industrial Commonwealth of Australia: Council for Scientific and Industrial
Research. Bulletin No. 143: Production of Dried Grapes in Murray Research. Bulletin No. 143: Production of Dried Grapes in Murray Valley Irrigation Settlements, 1 : Viticulture. By A. V. Lyon and D. Y. Walters. Pp. 48. Pamphlet No.112: Building-Frames ; Timbers and Sizes. (Division of Forest Products, Technical Paper No. 36.) By A. J. Thomas and Ian Langlands. Pp. 45. (Melbourne: Govern-
ment Printer.)

\section{Catalogues}

Ilford Kryptoscreen X-Ray Paper. Pp. 6. (London : Ilford, Ltd.) Catalogue of Books on Botany and Gardening with some items of Natural History. (No. 285.) Pp. 36. (Oxford: Dulau's Department, B. H. Blackwell, Ltd.)

Sulphonamide-P B.D.H. (Sulphanilamide) Pastes. Pp. 2. (London : British Drug Houses, Ltd.)

A Catalogue of Books and Periodicals on Botany, Agriculture, Forestry, Fruit-Culture, Gardens and Gardening, Herbals. (No. 598.) Pp. 64. (London: Bernard Quaritch, Ltd.)

Catalogue of a Private Library and Books from other Sources Pecently Purchased. (Catalogue No.660.) Pp. 94. (London: Francis Edwards, Ltd.)

Books on Science and its Applications and other New Acquisitions. (Catalogue 66.) Pp. 48. (London: E. P. Goldschmidt and Co., Ltd. 